\title{
CROSS-BORDER COMPARISON OF NON-FOREST WOODY VEGETATION IN THE WHITE CARPATHIANS (CENTRAL EUROPE) OVER LAST 65 YEARS
}

\author{
KATARÍNA DEMKOVÁ $^{1 *}$, MARTIN HAIS $^{2}$, MAGDA EDWARDS-JONÁŠOVÁ ${ }^{3}$ \\ ${ }^{1}$ Silva Tarouca Research Institute for Landscape and Ornamental Gardening, Publ. Res. \\ Inst., Květnové náměstí 391, 25243 Průhonice, Czech Republic, +420777106006 \\ ${ }^{2}$ Faculty of Science, University of South Bohemia in České Budějovice, Branišovská 1760, \\ 37005 České Budějovice, Czech Republic, e-mail: hais.martin@seznam.cz. \\ ${ }^{3}$ Global Change Research Institute CAS, Bělidla 986/4a, 60300 Brno, Czech Republic, \\ e-mail:edwards.m@czechglobe.cz. \\ *Corresponding authore-mail: demkova@vukoz.cz.
}

Received: $2^{\text {nd }}$ October 2018, Accepted: $21^{\text {th }}$ February 2019

\begin{abstract}
Landscape structure is determined by human activities and natural processes. Despite both influences are described in many studies, there remains still question, how the landscape structure reflects the individual socio-economic predictors. To answer this question we compared landscape structure, with emphasis on non-forest woody vegetation, of two states, however, with common socio-economic and political history. Non-forest woody vegetation represents characteristic feature in rural landscape, which increases water retention, biodiversity and bio-migration using green structures. In our study we supposed, that non-forest woody vegetation will have high sensitivity to societal changes and nature conservation measures. On an example of border region in former Czechoslovakia we compared three classes of non-forest woody vegetation (solitaires, patches and linear elements) in three time horizons $(1950,1986,2011)$. The most significant differences in spatial structure of non-forest woody vegetation between countries were in the number and area of solitaires, which decreased during the entire period. However, the largest solitaire decrease was in 1950-1986, mainly in correspondence with socialist collective farming. Moreover, the decrease was higher in the Slovak part compared to the Czech part. The primary reason for this was the removal of non-forest woody vegetation on one side and the joining crowns into bigger patches on the other side. The current trend of increasing area of patch and linear elements is related to natural succession. We assume that the main drivers of different development in non-forest woody vegetation in the border region after the split of Czechoslovakia were different management measures applied in nature and landscape conservation and social development.
\end{abstract}

Keywords: non-forest woody vegetation, landscape structure, nature conservation, landscape management, White Carpathians

\section{INTRODUCTION}

The landscape structure of Central and Eastern Europe rapidly changed in the last 65 years due to central planned economics until 1990s and then due to market economy until today 
(Bičík et al. 2001; Bässler \& Klotz, 2006; Kümmerle et al., 2009). Despite of the trend of landscape homogenization in recent years (Jongman, 2002), there is still a great variety of traditional cultural landscapes in Central Europe with typical landscape features such as balks, scattered trees, dry-stone walls, terraces, orchards etc. (Baran-Zgłobicka \& Zgłobicky, 2012; Lieskovský et al., 2014; Sklenička et al., 2009). Such landscape features are usually related with non-forested landscape (arable land, permanent grasslands), which is dependent on regular human intervention. Without any management it will be largely spontaneously overgrown by initial woody species (Plieninger et al., 2006; Sklenička et al., 2009). Land-use trends such as extensification and land abandonment especially in mountain areas are the biggest threat for non-forested landscape (Lieskovský et al., 2015; Kümmerle et al., 2008; Müller et al., 2013). Moreover, the exclusion of human influence can even lead to acceleration in species decline (MacDonald et al., 2000; Plieninger et al., 2006; Young et al., 2007).

One of the common features of European agricultural landscapes is non-forest woody vegetation (NFWV) or scattered greenery. It consists of stable woody vegetation, which is not a forest, an agricultural crop or part of the vegetation of settlements (sensu Bulír \& Škorpík, 1987). Natural elements growing spontaneously, as well as vegetation planted by humans, are included (groves, alleys, riparian vegetation, linear vegetation along roads, solitaires etc.). They have been conceptualized as "trees outside forests" (FAO, 2001). NFWV is important ecosystem service provider in landscape, especially ecologically, as wildlife habitats, corridors and refuges (Manning et al., 2006; McCollin et al., 2000); for erosion control (Baudry et al., 2000; Plieninger et al., 2004); for its microclimatic function (Jonsson et al., 1999; Sanchez et al., 2010); as boundary markers (Mojsej \& Petrovič, 2013; Sklenička et al. 2009) and as seed source (Manning et al., 2006). NFWV has a positive influence on visual quality of landscape, as well (Benčat' \& Jančura, 2008; Hunziker, 1995).

NFWV growing on grasslands depends directly on traditional farming practices such as cutting or grazing that started to become rare and less common. Land abandonment causes not only the loss of endangered meadow species but also changes in the landscape character resulting from overgrowth and loss of typical landscape features such NFWV. Because it is declining rapidly in agricultural landscape around the world (Barr \& Gillespie, 2000; Demková \& Lipský, 2013; Gibbons et al., 2008; Jongman, 2002; Sklenička et al., 2009), it is necessary to realize its importance and to protect it adequately.

The main aim of our study is a trans-boundary comparison of the changes in spatial structure of NFWV between the Czech Republic and Slovakia, and between the protected and unprotected part. There have been published a few cross-border researches in context of land use changes in Eastern European countries (Kümmerle et al., 2006, 2008). They investigated how does land use and landscape pattern differ in three post-socialist countries (Poland, Slovakia and Ukraine) along the border region of the Carpathians and how did farmland abandonment change after 1989. Although the study area is ecologically relatively homogenous, Kümmerle et al. (2006) showed marked differences in land cover between three countries. They concluded that broad-scale socio-economic and political factors are of major significance for land cover patterns in Eastern Europe. Farmland abandonment was widespread in the study area after 1989 with substantial differences among the countries. Differences are likely caused by different land ownership patterns, post-socialist land reform strategies and rural population density (Kümmerle et al., 2008).

Studying rates of changes and time trends in spatial pattern of NFWV in border regions may reveal the consequences of how differences in land ownership, land management policies and institutional change affect ecosystems and landscape structure. We suppose that 
Demková K., Hais M., Edwards-Jonášová M.: Cross-border comparison of non-forest woody vegetation in the White Carpathians (Central Europe) over last 65 years

NFWV is a great indicator for sensitivity of landscape on socio-economic changes such as management practices, nature conservation, rural population change etc.

\section{MATERIALS AND METHODS}

\section{Study area}

The study area is located in the southern part of the White Carpathians, which is cross-border region between the Czech Republic (CZ) and Slovakia (SK). Example of CZ and SK shows interesting developments of two countries living as one state (Czechoslovakia) for decades and separated into two new countries in 1993, both now members of the European Union. The common history includes several historical and political milestones (Table 1), which have influenced landscape development of the study area in the observed time period.

\section{Table 1: Common milestones in historical development of the Czech Republic and Slovakia}

\begin{tabular}{|c|c|c|}
\hline Time period & Historical event & Consequences \\
\hline $1948-1950 \mathrm{~s}$ & $\begin{array}{l}\text { The Communist coup deetat and the } \\
\text { following land collectivization }\end{array}$ & $\begin{array}{l}\text { Large-scale collective farming aimed at maximum } \\
\text { production of agricultural commodities (Fanta } \text { et al., } \\
\text { 2005); } \\
\text { Loss of relationship to soil; } \\
\text { Removal of NFWV and other typical landscape } \\
\text { features (Lipský, 1995). }\end{array}$ \\
\hline 1989 & Abolition of the socialist regime & $\begin{array}{l}\text { Restitution of private land ownership in the 1990s, } \\
\text { reintroduction of democracy and a market economy, } \\
\text { including agricultural commodities, development of } \\
\text { marked-driven forms of land-use (Fanta et al., 2005); } \\
\text { Loss of interest in unprofitable land management; } \\
\text { Overgrowth of existing NFWV. }\end{array}$ \\
\hline 1993 & Split of Czechoslovakia & $\begin{array}{l}\text { Different political and economic development (law, } \\
\text { management, subsidy policy); } \\
\text { Partially different approach to nature and landscape } \\
\text { conservation, different priorities in financial support } \\
\text { (Mertanová, 2013; personal communication). }\end{array}$ \\
\hline 2004 & Accession to the European Union & $\begin{array}{l}\text { Full association with the EU agricultural market, } \\
\text { introduction of principles of the Common } \\
\text { Agricultural Policy, searching for appropriate } \\
\text { methods and forms of land-use (Fanta } \text { et al., 2005); } \\
\text { Prioritizing the existence of larger farmers, ignoring } \\
\text { local ecological and social conditions in mountain } \\
\text { areas (Bezák \& Mitchley, 2014); } \\
\text { Protection and financial support of NFWV and other } \\
\text { stabilizing features on agricultural land. }\end{array}$ \\
\hline
\end{tabular}

The White Carpathians represent a unique border region in Central Europe, where the settlement continuity was not disturbed by the displacement of German population after the $2^{\text {nd }}$ World War in contrast to other border regions in the CZ. So consequently we expected a higher continuity of landscape management in White Carpathians over last 50 years.

The study area was delimited in accordance with the cadastral boundaries that define a basic administrative unit that has been more or less persistent since the first half of the $19^{\text {th }}$ 
century. Cadastral units enable to use socio-economic data in order to observe population or land use development. The study area with the total area of 7,930 ha (2,780 ha in $\mathrm{CZ}$ and 5,150 ha in SK) is located within upland terrain, whose altitudes vary from $250 \mathrm{~m}$ to $610 \mathrm{~m}$ a. s. 1. (Fig. 1). The natural conditions (topography, land cover) in the study area are relatively homogenous and therefore suited for trans-boundary comparison.

Fig. 1: Study area

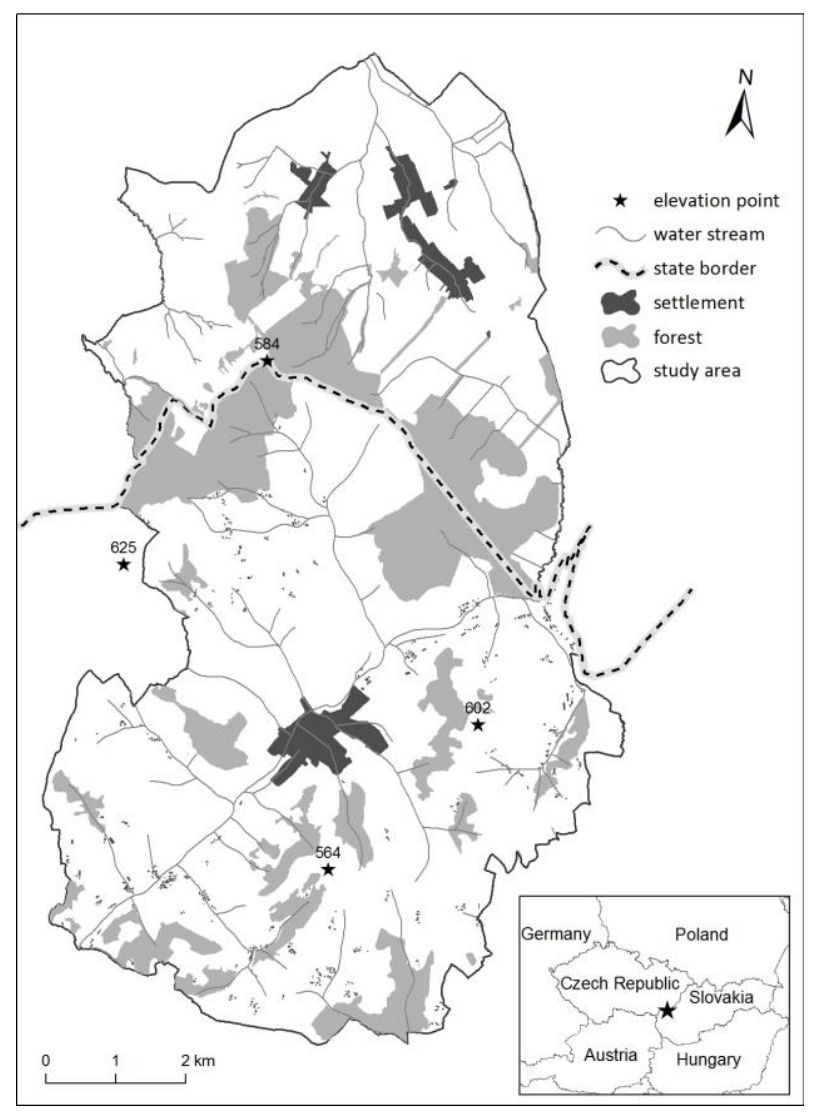

Current land cover was influenced particularly by forest-agricultural activities of the past centuries which resulted into the mosaic of forest, fields, meadows and pastures with NFWV as an essential part (Table 2). Although intensification of agriculture has affected these parts of the countries as well, the share of arable land has been continually decreasing to the benefit of permanent grasslands (particularly in the Slovak part).

A typical feature of the White Carpathians in the Slovak part is dispersed type of settlement, called "crofts", with a common center in a village. Crofts were formed as the consequence of lack of farmland in this part of country. In contrast, settlement in the Czech part of the study area is continuous (three small villages of road type).

As a consequence of high social and cultural diversity, the (bilateral) Protected Landscape Area (PLA) White Carpathians was declared in 1979/1980. However, it involves $80.4 \%$ of the study area in the Czech part and only $24.5 \%$ in the Slovak part. 
Demková K., Hais M., Edwards-Jonášová M.: Cross-border comparison of non-forest woody vegetation in the White Carpathians (Central Europe) over last 65 years

Table 2: Land cover in the study area

\begin{tabular}{|l|c|c|}
\hline Land use & $\begin{array}{c}\text { Czech part } \\
\text { (in \%; 2010) }\end{array}$ & $\begin{array}{c}\text { Slovak part } \\
\text { (in \%; 2006) }\end{array}$ \\
\hline Arable land & 45.4 & 40.5 \\
Permanent crop & 1.5 & 0.5 \\
\cline { 1 - 1 } Meadows and pastures & 26.9 & 19.7 \\
\cline { 1 - 1 } Landscape principally occupied by agriculture with significant & 0 & 15.2 \\
areas of natural vegetation & 20.7 & 21.4 \\
\cline { 1 - 1 } Woodland & 0.8 & 0.4 \\
\cline { 1 - 2 } Water areas & 1.1 & 2.3 \\
\hline
\end{tabular}

Source: CORINE Land Cover data (2006); http://lucc.ic.cz/

\section{Data collection}

To describe the main periods of landscape structure change three time horizons of aerial images were chosen - 1950 (reflect post-war landscape mosaic before socialist collectivization), 1986 (represent the forest-agricultural socialistic management) and 2011 (reflect different landscape management after the split of Czechoslovakia in 1993). All historical aerial images (technical parameters in Table 3) were orthorectified and transformed to the S-JTSK Krovak East North coordinate system.

\section{Table 3: Technical parameters of historical aerial images}

\begin{tabular}{|l|c|c|c|}
\hline Territory & Year & $\begin{array}{c}\text { Number of } \\
\text { images }\end{array}$ & $\begin{array}{c}\text { Spatial resolution } \\
(\mathrm{m})\end{array}$ \\
\hline Slovak part & 1949 & 4 & 0.466 \\
\hline & 1986 & 13 & 0.258 \\
\hline & 2006 & 7 & 0.476 \\
\hline Czech part & 1986 & 8 & 0.238 \\
\hline & $1950,2010^{*}$ & & 0.5 \\
\hline
\end{tabular}

* Orthophotos from the Czech Environmental Agency, nowadays available from the State Administration of Land Surveying and Cadastre

NFWV was first digitized from the 2010 orthophotos in CZ (The Czech Environmental Agency) and from the 2006 images in SK (The Topographical Institution of the Slovak Republic), which provided the best ground resolution. The present state of NFWV in the Slovak part was mapped in the field during the growing season of 2011 in order to gain information about changes in the last 5 years. After that, NFWV from historical aerial photographs (1950 and 1986) was identified. Because of the lower spatial resolution of the older images, NFWV was interpreted from each image on the screen, based on texture and tone. The data were collected only for non-forest areas and outside settlements.

Digitization of NFWV proceeded according to following parameters (Bulír \& Škorpík, 1987; Sláviková, 1984; Supuka et al., 1999) in ArcGIS environment:

- Patch elements - group of trees and/or shrubs, maximum area of 0.3 ha (small woods, groves, vegetation on marshland, on abandoned lands or localities unsuitable for any economic use);

- Linear elements - one or more lines of vegetation with minimum length of $30 \mathrm{~m}$, maximum width of $30 \mathrm{~m}$, at the same time width is maximally $30 \%$ of length 
(alleys, riparian vegetation, linear vegetation along railways, on balks etc.);

- Point elements - one to three individuals of tree or shrub (solitaire, group of trees, shrubs), minimal area of $5 \mathrm{~m}^{2}$.

The area of NFWV was set down as a projection of the tree or the shrub crown.

\section{Landscape-ecological analysis}

For quantification of spatial structure of NFWV, three regular grids with different cell size $(100 \mathrm{~m}, 500 \mathrm{~m}$ and $1000 \mathrm{~m})$ were generated. Each quadrant cell was assigned a degree of protection (protected or not protected) according to whether the center of the quadrant cell occurred in the protected landscape area or not in relevant year. NFWV of the Czech and Slovak parts separately were overlaid by each grid. Quadrants which were covered by less than $40 \%$ of the study areas were excluded from the analysis. Using Patch Analyst extension for ArcGIS (Rempel et al., 2012), basic landscape-ecological metrics (Table 4) for each time horizons (1950, 1986 and 2011) were counted.

\section{Table 4: Landscape-ecological metrics used for landscape microstructure analysis (McGarigal et al. 2002)}

\begin{tabular}{|l|c|c|}
\hline Metrics & Abbreviation & Description \\
\hline Class area & AREA & The total area of all polygons in the class (ha) \\
\hline Number of polygons & NUM & The total number of polygons in the class \\
\hline Mean polygon size & MPS & The average area of all polygons in the class (ha) \\
\hline Total edge & PER & $\begin{array}{c}\text { The total length of perimeter of all polygons in the } \\
\text { class (m) }\end{array}$ \\
\hline Mean shape index & MSI & $\begin{array}{c}\text { Measure of the average polygon shape for all } \\
\text { polygons in the class }\end{array}$ \\
\hline
\end{tabular}

\section{Statistical analysis}

The landscape-ecological metrics were analyzed by Redundancy Analysis (RDA) using Canoco 5 (ter Braak \& Śmilauer, 2012), with time (1950, 1986, 2011), state (CZ, SK), and protection (in the PLA, outside of the PLA) used as nominal explanatory variables. Individual analyses revealed the percent variability in the response data explainable by a particular explanatory variable, as well as by combination of all variables and by their interaction. The significance of the effects of explanatory variables was tested by Monte Carlo permutation test and both simple (contribution of a variable without using the other variables) and conditional (unique contribution of a variable adjusted for the effect of the other variables) effects were evaluated. Spatial and temporal autocorrelation of the data was accounted within the permutation test using a split-plot design. The data for each size of grid $(100 \mathrm{~m}, 500 \mathrm{~m}$ and $1000 \mathrm{~m})$ and classes of NFWV (point, patch and linear elements) were analyzed separately. The landscape-ecological metrics data were standardized by species.

\section{RESULTS}

RDA analysis processed for each size of grid $(100 \mathrm{~m}, 500 \mathrm{~m}$ and $1000 \mathrm{~m})$ showed that the explained variability in data describing occurrence of NFWV increases with the size of grid. Therefore the following analyses concentrated only on data in a grid with a size of $1000 \mathrm{~m}$.

The highest variability was explained for point elements data $(\mathrm{S})$ and the smallest for patch elements data (P) (Table 5). 
Demková K., Hais M., Edwards-Jonášová M.: Cross-border comparison of non-forest woody vegetation in the White Carpathians (Central Europe) over last 65 years

Table 5: Results of RDA analysis for point $(S)$, patch $(P)$ and linear $(L)$ elements data obtained from squares of $1000 \mathrm{~m}$

\begin{tabular}{|l|l|c|c|c|c|}
\hline Data & Explanatory variables & $\begin{array}{c}\text { Explained } \\
\text { variability (simple } \\
\text { effect) }\end{array}$ & $\mathrm{p}$ & $\begin{array}{c}\text { Explained variability } \\
\text { (conditional effect) }\end{array}$ & $\mathrm{p}$ \\
\hline $\mathrm{S}$ & Time & 7.7 & 0.002 & 7.7 & 0.002 \\
& State & 7.9 & 0.002 & 5.0 & 0.002 \\
& Protection & 3.5 & 0.002 & 0.6 & 0.052 \\
& All & 17.6 & 0.002 & & 0.004 \\
\hline L & Time x State x Protection & 23.2 & 0.002 & 4.9 & 0.002 \\
& Time & 4.2 & 0.002 & 0.9 & 0.016 \\
& State & 0.1 & 0.27 & 3.0 & 0.002 \\
& Protection & 2.2 & 0.002 & & 0.054 \\
\hline P & All & 8.7 & 0.002 & 4.4 & 0.002 \\
& Time x State x Protection & 12.8 & 0.002 & 2.7 & 0.002 \\
& Time & 2.6 & 0.004 & 2.4 & 0.61 \\
& State & 2.4 & 0.002 & 0.0 & 0.002 \\
\hline
\end{tabular}

For individual variables, the most important effect in all classes was time. The influence of state and protection on spatial pattern of NFWV classes proved to be different. The effect of protection was insignificant in cases of patch elements and very small for point and linear elements, while the effect of state was insignificant in cases of linear NFWV and was relatively high for point elements (Table 5). The interaction of used variables proved the highest explained variability for all three classes. Generally, the effect of variables is not large. It differs according to time, state and degree of protection.

Time development of the spatial structure of point elements in the Czech and Slovak parts of the White Carpathians is very different (see Fig. 2). The direction, as well as the degree of change, differs between states and time horizons. The values of AREA, NUM, PER and MSI decreased in Slovakia from 1950, a bigger decrease was noticed between 1950 and 1986. In the Czech part, MPS increased from 1950 but on the other hand, NUM and PER decreased during the same time (Fig. 3). The direction of change is similar in both parts of the Czech study area - protected $(\mathrm{P})$ and also not protected $(\mathrm{N})$. The differences between them are in the degree of change, which is bigger in the protected part. 
Fig. 2: RDA ordination diagram for data describing occurrence of point elements of NFWV in landscape of White Carpathians with interaction of State, Time and Protection used as explanatory variables.

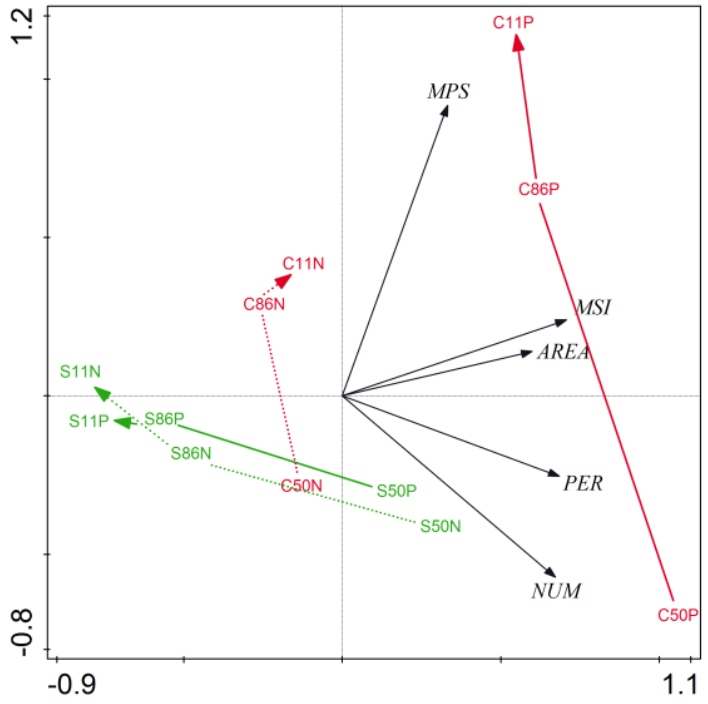

Notes: C - Czech Republic, S - Slovakia; 50, 86, 11 - years 1950, 1986, 2011; P - protected area, $\mathrm{N}$ - unprotected area

Fig. 3: RDA ordination diagram for data describing occurrence of linear elements of NFWV in landscape of the White Carpathians with interaction of State, Time and Protection used as explanatory variables.

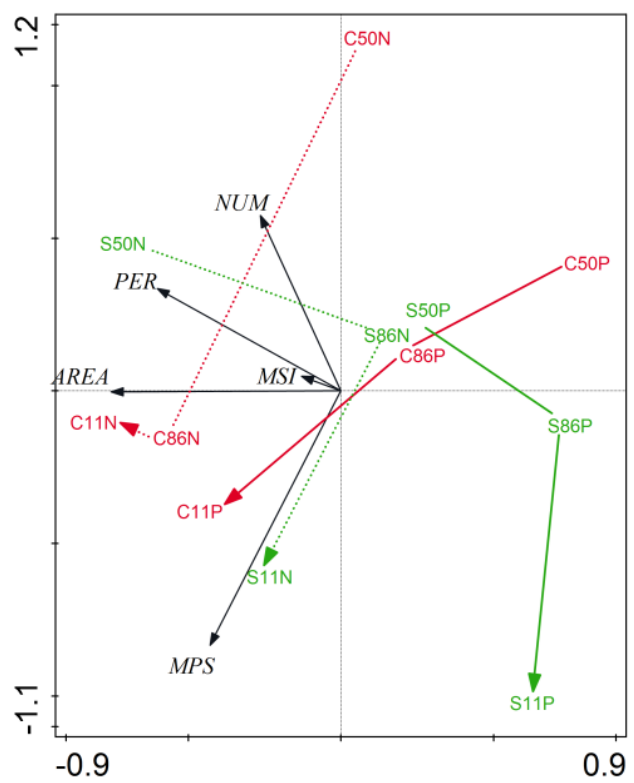

Notes: C - Czech Republic, S - Slovakia; 50, 86, 11 - years 1950, 1986, 2011; P - protected area, $\mathrm{N}$ - unprotected area 
Demková K., Hais M., Edwards-Jonášová M.: Cross-border comparison of non-forest woody vegetation in the White Carpathians (Central Europe) over last 65 years

The time development of linear elements of NFWV differs between states and also protected and unprotected areas (Fig. 3). Time trends in the Slovak parts are very similar in protected as well as unprotected areas. In both cases, values of AREA and PER decreased between 1950 and 1986 but the decrease was bigger but the decrease was bigger in unprotected area. In next period (1986-2011), MPS rose but NUM decreased. Values of AREA, PER and NUM are bigger in unprotected areas during the entire observation period, which is also characteristic for the Czech part of the study area. Different time development between protected and unprotected areas began after 1986. Values of MPS and AREA rose in both cases between 1950 and 1986. This trend continued in protected area and also in the next time period, while in unprotected area values of AREA increased slightly but MPS did not change (Fig. 3).

As mentioned previously, protection does not play any role in the time trends of spatial structure of patch elements in the White Carpathians. Significant differences were recognized between states (Fig. 4). Generally, values of MPS and MSI are smaller in the Czech part than in the Slovak during the entire observed period. Big differences in all metrics were recorded in 1950. In the next time periods these differences between states have decreased slightly.

The time development of metrics is very different. In the Slovak part, decrease of PER, NUM and AREA was observed (especially between 1950 and 1986). Between 1986 and 2011 MPS rose and values of MSI decreased. Comparing with the Slovak part, time trends in the Czech part are in conflict (Fig. 4). While MPS rose and MSI decreased between 1950 and 1986, between 1986 and 2011 values of PER, NUM and AREA rose, MSI only slightly and MPS decreased (vice versa in the Slovak part).

Fig. 4: RDA ordination diagram for data describing occurrence of patch elements of NFWV in landscape of White Carpathians with interaction of State, Time and Protection used as explanatory variables.

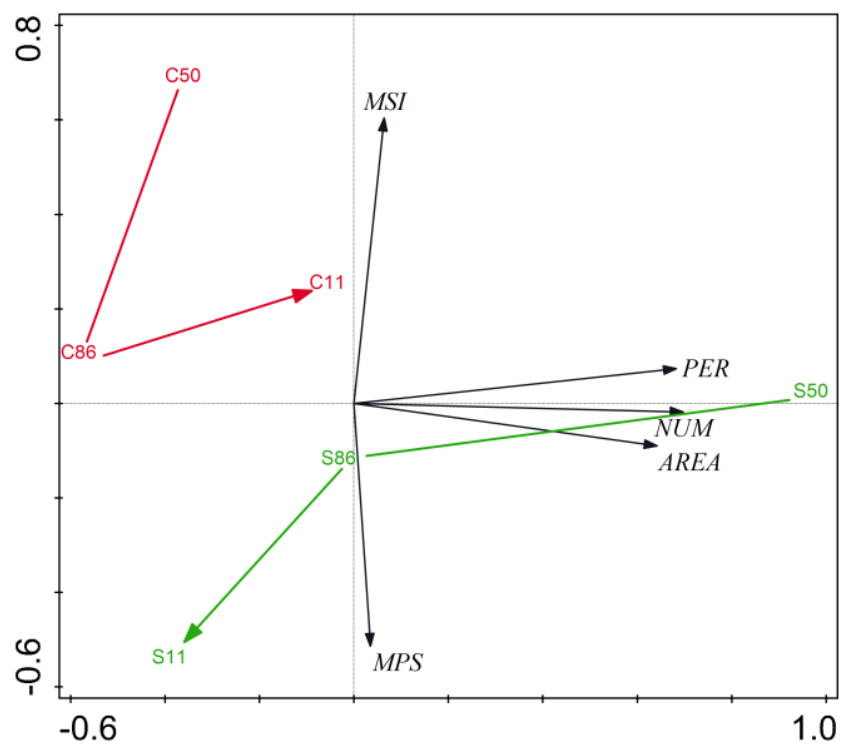

Notes: C - Czech Republic, S - Slovakia; 50, 86, 11 - years 1950, 1986, 2011; P - protected area, $\mathrm{N}$ - unprotected area 


\section{DISCUSSION}

NFWV is considered to be a keystone landscape structure because it provides many important ecosystem services (Plieninger et al., 2004) and has a disproportionately large effect on the ecosystem relative to the area it occupies (Manning et al., 2006). Scattered trees are often the oldest living structures in disturbed landscape and provide important ecological continuity through time (Manning et al., 2006). In general, NFWV represents very sensitive landscape feature in landscape structure because of its low economical value, which has been crucial in the last 65 years. Over that time, the European landscape has significantly changed due to political shifts/interventions (Primdahl et al., 2013) and socio-economic consequences influencing forest-agricultural management, nature conservation. Generally, landscape structure has been homogenized (Jongman, 2002; van Zanten et al., 2014) which has affected ecosystems and landscape character (aesthetic values). Furthermore, boundary regions typically located in mountains were abandoned and marginalized resulting in decrease of socio-economical activities (e.g. Kümmerle et al., 2006, 2008; Demková \& Lipský, 2015). This trend is supported also by our findings.

In general, differences in rates and spatial structure of NFWV between protected and unprotected areas were not significant. On the contrary, states differ in time trends of all types of NFWV. Observed time trends in the first time horizon (1950-1986) relate with socialist collective farming, societal changes and the abandonment of hard accessible land parcels. Market-oriented farming, the split of the former Czechoslovakia, the accession to the European Union and socio-economic differences influenced spatial structure of NFWV in the second period (1986-2011).

A decrease in all metrics in the Slovak part, especially in the first period, was caused either by removing NFWV during land re-allotment or by transforming abandoned land into forest. Milder increase in area and mean polygon size of NFWV in the next period (especially due to widening linear elements) resulted from ongoing land abandonment. Values of area, number of polygons and total edge were higher during the entire time period in the unprotected area. It is not suited to keep NFWV widening or enlarging in the PLA because the main objective of protection in the PLA is the orchid family growing on meadows.

In the Czech part, a decrease of NFWV in number of polygons and partially in area between 1950 and 1986 is related to the land re-allotment and conversion of NFWV to forest or linear elements. The gradual increase in mean polygon size of solitaires was probably caused by the maintenance of unique spatial structure of solitaires in a part of the study area during socialist farming. On the other hand, an increase in mean polygon size of linear vegetation resulted from foundations of shelterbelts and natural spreading, e.g. along water streams. Ongoing increasing mean polygon size and area of NFWV in next period is related to its natural increasing crown projection. Higher value of number of polygons was recognized only in this period in the case of patch elements, which was caused either by formation of new patches on places unsuitable for farming or by joining neighboring solitaires.

The observed NFWV changes (reduction in number of polygons and an increase in mean polygon size) follow the general trend of land cover changes in Western Europe during the agricultural industrialization (Hamre et al., 2007; Ihse, 1995) and in Eastern Europe during socialist intensification and collectivization (Bičík et al., 2001; Lipský, 1995). Land cover changes have been triggered by a development of new agricultural technology that allows more effective farming over larger areas (Fjellstad \& Dramstad, 1999; van Eetvelde \& Antrop, 2004). Our findings pointed out that socialist collectivization enhanced the impact on agricultural landscape structure as it was also confirmed in other Central and Eastern 
Demková K., Hais M., Edwards-Jonášová M.: Cross-border comparison of non-forest woody vegetation in the White Carpathians (Central Europe) over last 65 years

European countries (Lieskovský et al., 2014; Skaloš \& Engstová, 2010; Takács-György et al., 2007). Finally, we can conclude that NFWV is a great indicator of landscape structure changes.

Although we studied a relatively environmentally homogenous region with similar historic development, changes in landscape structure can differ significantly. Similar conclusions were published by Kümmerle et al. $(2006,2008)$ along the border region of the Carpathians. Compared to our study area, land-ownership pattern and societal development (rural population density and emigration) appear to be important drivers of different development of landscape structure as well. While in the Slovak part mostly large parcels from collectivization period have persisted, land-ownership pattern in the Czech part is more diverse with the occurrence of small strip fields remain until the present. The decrease in population density since 1950 was similar in both parts however population density is higher in the Czech part during the entire observed period (see Table 6). The split of Czechoslovakia probably supported population decrease in borderland, as well. Moreover, dispersed settlement in the Slovak part affects greatly population development and landscape abandonment. The aging of the rural population, emigration and conversion of permanently inhabited houses into recreational houses have had substantial impact on landscape structure and the landscape character of the study area. The risk of adverse age structure of farmers for further rural development in the Czech PLA White Carpathians is also outlined in Špička (2009). Similar trends are even more intensively identified by Turnock (2002) and Kümmerle et al. (2009) in the Carpathian mountain region.

Table 6: Population and permanently inhabited housing development in the study area (1950-2011)

\begin{tabular}{|l|c|c|c|c|c|c|c|c|c|}
\hline & \multicolumn{4}{|c|}{ Inhabitants } & \multicolumn{3}{c|}{ Population density $\left(\mathrm{No} / \mathrm{km}^{2}\right)$} & \multicolumn{3}{c|}{ Permanently inhabited houses } \\
\cline { 2 - 11 } & 1950 & 1991 & 2011 & 1950 & 1991 & 2011 & 1950 & 1991 & 2011 \\
\hline Czech part & 1851 & 1437 & 1271 & 66.6 & 51.7 & 45.7 & 479 & 467 & 371 \\
\hline Slovak part & $2591^{*}$ & 1663 & 1549 & 50.3 & 32.1 & 30.1 & $648^{* *}$ & 566 & 493 \\
\hline
\end{tabular}

*1961, **1970; Source: http://czso.cz/, http://slovak.statistics.sk/

Landscape structure in the Slovak part became less heterogenic due to the decrease of area and number of patch and point elements between 1986 and 2011, although the area of linear elements increased. Patches and solitaires which disappeared were situated mostly on steep slopes and less accessible land. Grasslands started to be overgrown successively as a consequence of the absence of interest of the owners in farming. Moreover, since 2008 budget cuts for administrations for PLA have significantly affected the performance of management measures expendable for the maintenance of biodiversity (Mertanová, 2013; personal communication). Therefore important natural localities are managed by the staff of the PLA and supported by local NGOs. Summer work camps for volunteers are organized annually and hay is removed from the localities (Mertanová et al., 2010).

The most significant difference between the Czech and Slovak parts was in solitaires number and area in the second time period (1986-2011). It can be explained by differences in financial instruments in the field of nature and landscape conservation between countries. National subsidies in the Czech Republic enable the removal of unwanted self-seeding plants on grasslands or the planting of new trees (mostly solitaires) which replace the old ones (Mertanová, 2013; personal communication). Such financial support enables maintenance and regeneration of the unique microstructure of NFWV in the Czech part of 
the White Carpathians. Moreover, since 2009 solitaires, groups of trees and tree lines together with other landscape features on agricultural land are protected in the Czech Republic (in Slovakia since 2015) and also financially supported by European agricultural subsidies because they have positive effect on agricultural landscape in many ways as previously mentioned. It is curious that NFWV and many other stabilizing landscape elements on agricultural land were intentionally removed during the socialist regime due to intensification and mechanization of agriculture (Bässler \& Klotz, 2006; Lipský, 1995).

\section{CONCLUSION}

NFWV is sensitive indicator of landscape structure changes in rural landscape. The main driving forces, which have markedly affected spatial structure of NFWV in the border region of the White Carpathians in Slovakia and the Czech Republic in the last 65 years, were socialist farming practices (e.g., collectivization, land re-allotment), land abandonment and social development (rural depopulation). In our study, we found that the most significant differences between countries were in number and area of solitaires, which decreased during the entire observed time. However, the largest decreases were between 1950 and 1986, mainly in correspondence to socialist farming. Furthermore, the decrease in solitaires number was higher in the Slovak study area in the next period due to the removal and joining of tree crowns into bigger patches. Different societal changes and management measures applied in landscape and nature conservation after the split of Czechoslovakia enhanced differences in landscape structure between the two countries along the border region.

\section{ACKNOWLEDGEMENTS}

This work was financially funded by institutional support from the Silva Tarouca Research Institute for Landscape and Ornamental Gardening (VUKOZ-IP-00027073) and by the Ministry of Education, Youth and Sports of CR within theNational Sustainability Program I (NPU I), grant number LO1415“.

\section{REFERENCES}

Baran-Zgłobicka, B. \& Zgłobicki W. (2012). Mosaic landscapes of SE Poland: should we preserve them? Agro. for Syst. 85, 351-365.

Barr, C.J. \& Gillespie M.K. (2000). Estimating hedgerow length and pattern characteristics in Great Britain using Countryside Survey data. J. Environ. Manage. 60, 23-32.

Baudry. J., Bunce R.G.H. \& Burel F. (2000). Hedgerows: An international perspective on their origin, function and management. J. Environ. Manage. 60, 7-22.

Bässler, C. \& Klotz S. (2006). Effects of changes in agricultural land use on landscape structure and arable weed vegetation over the last 50 years. Agric. Ecosyst. Environ. 115, 43-50.

Benčat', T. \& Jančura P. (2008). The importance and function of woods in landscape character. In T. Benčat', P. Jančura, \& D. Daniš (Eds.), Selected problems of landscape in submountain and mountain areas (5-8 p.), Poniky, Publishing of Janka Čižmárová - Partner. Bíčík, I., Jeleček L. \& Štěpánek V. (2001). Land use changes and their social driving forces 
Demková K., Hais M., Edwards-Jonášová M.: Cross-border comparison of non-forest woody vegetation in the White Carpathians (Central Europe) over last 65 years

in Czech Republic in the $19^{\text {th }}$ and $20^{\text {th }}$ century. Land Use Policy, 18, 65-73.

Bulír. P. \& Škorpík M (1987). Scattered greenery in landscape. News from the Research and Breeding Institute for Ornamental Gardening in Průhonice, O. P. Sempra, Praha.

CORINE Land Cover (2006). Slovak Environmental Agency, Slovak Republic, 1:50,000.

Demková, K. \& Lipský Z. (2013). Changes in the extent of non-forest woody vegetation in the lowland of Novodvorsko and Žehušicko region (Central Bohemia, Czech Republic). AUC Geographica 48, 5-13.

Demková, K. \& Lipský Z. (2015). Changes of non-forest woody vegetation in the southwestern part of White Carpathians between 1949-2011. Geografie, 120, 64-83.

Fanta, J. Zemek F. \& Prach K. (2005). Roots of marginalization across a Czech border area and its future landscape perspectives. Non-published report for the concerted action EUROLAN project (QLK5-CT-2002-02346).

FAO (2001). Trees outside the forest: Towards rural and urban integrated resources management. Contribution to the forest resources assessment 2000 report. FAO Forest Conservation, Research and Education Service, Rome.

Fjellstad, W.J. \& Dramstad W.E. (1999). Patterns of change in two contrasting Norwegian agricultural landscapes. Landsc. Urban Plan. 45, 177-191.

Gibbons, P., Lindenmayer D.B., Fischer J., Mening A.D., Weinberg A., Seddon J., Ryan P. $\&$ Barrett G. (2008). The future of scattered trees in agricultural landscapes. Conserv. Biol. 22, 1309-1319.

Hamre, L.N., Domaas S.T., Austad I. \& Rydgren K. (2007). Land-cover and structural changes in a western Norwegian cultural landscape since 1865, based on an old cadastral map and a field survey. Landsc. Ecol. 22, 1563-1574.

Hunziker, M. (1995). The spontaneous reafforestation in abandoned agricultural lands: perception and aesthetic assessment by locals and tourists. Landsc. Urban Plan. 31, 399-410.

Ihse, M. (1995). Swedish agricultural landscapes - patterns and changes during the last 50 years, studied by aerial photos. Landsc. Urban Plan. 31, 21-37.

Jongman, R.H.G. (2002). Homogenisation and fragmentation of the European landscape: ecological consequences and solutions. Landsc. Urban Plan. 58, 211-221.

Jonsson, K., Ong C.K. \& Odongo J.C.W. (1999). Influence of scattered nere and karite trees on microclimate, soil fertility and millet yield in Burkina Faso. Exp. Agr. 35, 39-53.

Kümmerle, T., Radeloff V.C., Perzanowski K. \& Hostert P. (2006). Cross-border comparison of land cover and landscape pattern in Eastern Europe using a hybrid classification technique. Remote Sens. Environ. 103, 449-464.

Kümmerle, T., Hostert P., Radeloff V.C., Perzanowski K. \& Kruhlov I. (2008). Cross-border comparison of post-socialist farmland abandonment in the Carpathians. Ecosystems, 11, 614-628.

Kümmerle, T., Müller D., Griffiths P. \& Rusu M. (2009). Land use change in Southern Romania after the collapse of socialism. Reg. Environ. Change, 9, 1-12.

Lieskovský, J., Kenderessy P., Špulerová J., Lieskovský T., Koleda P., Kienast F. \& Gimmi U. (2014). Factors affecting the persistence of traditional agricultural landscapes in Slovakia during collectivization of agriculture. Landsc. Ecol. 29, 867-877.

Lieskovský, J., Bezák P., Špulerová J., Lieskovský T., Koleda P., Dobrovodská M., Bürgi M. 
\& Gimmi U. (2015). The abandonment of traditional agricultural landscape in Slovakia Analysis of extent and driving forces. J. Rural Stud. 37, 75-84.

Lipský, Z. (1995). Changing face of Czech rural landscape. Landsc. Urban Plan. 31, 39-45. MacDonald, D., Crabtree J.R., Wiesinger G., Dax T., Stamou N., Fleury P., Gutierrez Lazpita J. \& Gibon A. (2000). Agricultural abandonment of mountain areas in Europe: Environmental consequences and policy response. J. Environ. Manage. 59, 47-69.

Manning, A.D., Fischer J. \& Lindenmayer D.B. (2006). Scattered trees are keystone structures - implications for conservation. Biol. Conserv. 132, 311-321.

McCollin, D., Jackson J.I., Bunce R.G.H., Barr C.J. \& Stuart R. (2000). Hedgerows as habitat for woodland plants. J. Environ. Manage. 60, 77-99.

McGarigal, K., Marks B.J., Holmes C. \& Ene E. (2002). Fragstats 3.3 [computer software]. Retrieved September 8, 2003, from http://www.umass.edu/landeco/research/ fragstats/downloads/fragstats_downloads.html

Mertanová, S., Rajcová K. \& Jánský P. (2010). Providing adequate grassland management in Slovakia - case studies from the Biele Karpaty Mts. Proceedings of the $7^{\text {th }}$ European Dry Grassland Meeting: Succession, restoration and management of dry grasslands, p. 46.

Mojsej, M. \& Petrovič F. (2013). Land use changes of historical structures in the agricultural landscape at the local level - Hriňová case study. Ekol. Bratislava, 32, 1-12.

Müller, D., Leitão P.J. \& Sikor T. (2013). Comparing the determinants of cropland abandonment in Albania and Romania using boosted regression trees. Agric. Syst. 117, 66-77.

Plieninger, T., Pulido F.J. \& Schaich H. (2004). Effects of land-use and landscape structure on holm oak recruitment and regeneration at farm level in Quercus ilex L. dehesas. J. Arid Environ. 57, 345-364.

Plieninger, T., Höchtl F. \& Spek T. (2006). Traditional land-use and nature conservation in European rural landscapes. Environ. Sci. Policy, 9, 317-321.

Primdahl, J., Kristensen L. \& Swaffield S. (2013). Guiding rural landscape change. Current policy approaches and potentials of Landscape strategy making as a policy integrating approach. Appl. Geogr. 42, 86-94.

Rempel, R.S., Kaukinen D. \& Carr A.P. (2012). PatchAnalyst and PatchGrid. ThunderBay, Ontario: Ontario Ministry of Natural Resources, Centre for Northern Forest Ecosystem Research.

Sanchez, I.A., Lassaletta L., McCollin D. \& Bunce R.G.H. (2010). The effect of hedgerow loss on microclimate in the Mediterranean region: an investigation in Central Spain. Agro. for Syst. 78, 13-25.

Skaloš, J. \& Engstová E. (2010). Methodology for mapping non-forest wood elements using historic cadastral maps and aerial photograps as a basis for management. J. Environ. Manage. 91, 831-843.

Sklenička, P., Molnárová K., Brabec E., Kumble P., Pittnerová B., Pixová K. \& Šálek M. (2009). Remnants of medieval field patterns in the Czech Republic: Analysis of driving forces behind their disappearance with special attention to the role of hedgerows. Agric. Ecosyst. Environ. 129, 465-473.

Sláviková, D. (1984). The importance of forest and scattered greenery in landscape design. Zvolen: University of Forestry and Wood Sciences.

Supuka, J., Schlampová T. \& Jančura P. (1999). Landscape design. Zvolen: Technical 
University.

Špička, J. (2009). Farming under environmental conditions in the Beskyds and White Carpathians. Agric. Econ. - Czech, 55, 459-466.

Takács-György, K., Bandlerova A. \& Sadowski A. (2007). Land Use and Land Reform in Former Central and East European Countries. European Association of Agricultural Economists $104^{\text {th }}$ Seminar, Corvinus University of Budapest, pp. 1-13.

terBraak, C.J.F. \& Šmilauer P. (2012). Canoco reference manual and user's guide: software for ordination (version 5.0) [computer software]. Ithaca, NY, USA: Microcomputer Power.

Turnock, D. (2002). Ecoregion-based conservation in the Carpathians and the land-use implications. Land Use Policy, 19, 47-63.

Van Eetvelde, V. \& Antrop M. (2004). Analyzing structural and functional changes of traditional landscape - two examples from Southern France. Landsc. Urban Plan. 67, 79-95.

van Zanten, B.T., Verbung P.H., Espinosa M. et al (2014). European agricultural landscapes, common agricultural policy and ekosystém services: a review. Agron. Sustain. Dev. 34, 309-325.

Young, J., Richards C., Fischer A., Halada L., Kull T., Kuzniar A., Tartes U., Uzunov Y. \& Watt A. (2007). Conflicts between biodiversity conservation and human activities in the central and eastern European countries. Ambio, 36, 545-5.

\section{Web references}

Czech Environmental Information Agency (CENIA) (2010). Present and historical aerial photographs available. Retrieved December 15, 2011, from http://geoportal.cenia.cz

Czech Statistical office. Retrieved January 15, 2014, from http://czso.cz

Database of long-term changes in land use of the Czech Republic 1845-2000. Retrieved April 20, 2014, from http://lucc.ic.cz

Statistical office of the Slovak Republic. Retrieved January 30, 2014, from http://slovak.statistics.sk 